\title{
Effect of sowing dates and fertilization treatments on productivity of barley crop under
}

\section{Upper Egypt conditions.}

\author{
Abd El-Lattief, E.A.*, M.A. Ali and H.M. Hmadi \\ Department of Agronomy, Faculty of Agriculture, South Valley University, Qena, Egypt.
}

\begin{abstract}
A study was conducted during 2016-2017 and 2017-2018 seasons at the Experimental Farm, Faculty of Agriculture, South Valley University, Qena, Egypt, with the objective to study the effect of different date of sowing and fertilization treatments on productivity of barley cultivar Giza 121. The experiment was in a splitplot arrangement was based on a randomized complete block design (RCBD) with three replications. Three sowing dates were assigned to the main plots and thirteen fertilization treatments to the sub-plots. There was a significant effect of the interaction between sowing dates and fertilization treatments on study traits (plant height, spike length, spike weight, number of spikes $/ \mathrm{m}^{2}, 1000$-grain weight, grain yield/plant, grain yield per feddan and straw yield per feddan). The highest values of previous traits were recorded under sowing barley cultivar Giza 121 at $15^{\text {th }}$ of November and applied of $75 \%$ recommended NPK + biofertilization + humic acid.
\end{abstract}

Keywords: Biofertilizer; humic acid; NPK; Sowing date.

\section{Introduction}

Barley (Hordeum vulgare L.) is cultivated successfully in a wider range of environmental conditions of all over the world. In Egypt, it is grown in some areas as a winter cereal crop which is cultivated mainly for grain production. It can also be grown as a dual purpose crop for providing good quality fodder as well as grains. The cutting at early stage at about 50-55 days after sowing provides good quality of fodder particularly in lean period (Mid December to mid-January) for feeding to the animals Singh et al. (2017).

Date of sowing is one of the important factors for higher production as it determines the optimum time of sowing of the crop. An optimum time of sowing enhances the efficiency of barley by exploiting growth

\footnotetext{
*Corresponding author: Essam A. Abd El-Lattief, Email: essameldeen@agr.svu.edu.eg

Received: June 22, 2021; Accepted: July 16, 2021;

Published online: July 30, 2021.

(C) Published by South Valley University.

This is an open access article licensed under (c)(1)(2)
}

factors in an effective manner. As dual purpose barley plant provides green fodder during lean period, the right time of sowing for availability of green fodder for longer time should be optimally utilized and therefore, the effects of various dates of sowing on dual purpose barley are quite remarkable (Singh et $a l ., 2017)$. Very early planting may expose the crop to higher temperature at tillering stage while late planting may results in low biomass production and poor grain development due to higher temperature conditions at the time of maturity (Nass et al., 1975; Ram et al., 2010). Early sowing date of barley recorded higher yield in comparison to late sown crop (Chaudhary et al., 2017; Pal et al., 2018; Potterton and McCabe, 2018; Amarjeet et al., 2020; Al Myali et al., 2020). Delay in planting decreases barley grain yield (Bavei and Vaezi, 2012; Devi et al., 2018)

In order to meet the food demands of a growing world population, agriculture sectors have been increasingly using chemical fertilizer. Chemical fertilizers are mainly a 
mixture of substances, such as nitrogen, phosphorus and potassium. The excess uses of chemical fertilizers in agriculture are costly and also have various harmful effects (Santos et al., 2012).

In this regard, organic fertilizers and biofertilizers have become alternative sources (Odgerel and Tserendulam, 2016). As compared to chemical fertilizers, biofertilizers are eco-friendly and cost effective. Biofertilizers contain various microorganisms that provide all kinds of micro and macro elements via nitrogen fixation, phosphate and potassium solubilization or mineralization, release of plant growth promoting substances, production of antibiotics and biodegradation of organic matter in the soil (Goel et al., 1999; Sinha et al., 2010). When biofertilizers are used continuously for many years, parental inoculums become sufficient for further multiplication (Youssef and Eissa, 2014), hence they participate in nutrient cycling and benefit crop productivity (Sing et al., 2011). Main benefits of biofertilizers are cheap source of nutrients, suppliers of microelements, suppliers of organic matter, counteracting negative impact of chemical fertilizers, secretion of growth hormone (Gaur et al., 2010). Organic, bio and minerals fertilization are considered among the most important cultural practices for increasing barley productivity and improved quality parameters. Modern agriculture, which largely depends on chemical fertilizers, pesticides, herbicides etc., though increased production, has adversely affected the soil productivity and environmental quality. The combined use of organic and inorganic fertilizers not only increases the crop yield but also improve the physical and biological properties of soil (Shashidhar et al., 1995)

The application of nitrogen alone and biofertilizer treatment significantly increased grain yield and grains per spike of barley cultivars (Al-Otayk, 2009). The application of urea, compost and biofertilizer as well as their combinations significantly, increased grain yields, grain weight/spike and 1000-grain weight (Helmy et al., 2013). The combination between treatments of NPK (at half dose) + FYM + biofertilizers recorded the highest grain yield, straw yield and grain protein content of wheat crop (Abd El-Lattief, 2014).

For that reason, the current study was performed to assess the effect of sowing dates and fertilization treatments on productivity of barley under Upper Egypt conditions.

\section{Materials and methods}

\subsection{Experimental site description}

The study was carried out at the Experimental Farm of South Valley University, Qena, Egypt during the two growing seasons 2016/2017 and $2017 / 2018$ to evaluate effect of sowing date and fertilization treatments on productivity of barley cv. Giza 121 under Upper Egypt conditions. The farm is located at an altitude of $79 \mathrm{~m}$ above mean sea level and is intersected by $26^{\circ} 10^{\prime} \mathrm{N}$ latitude and $32^{\circ} 43^{\prime}$ E longitude. Soil physical and chemical properties as depicted in Table 1. Detailed climatic parameters for Qena are given in Table 2.

\subsection{Experimental treatments and design}

The experiment was in a split-plot arrangement was based on a randomized complete block design (RCBD) with three replications. Sowing dates $\left(D_{1}\right.$-sowing at $1^{\text {st }}$ of November, $D_{2}-15$ th of November and $D_{3}-1^{\text {st }}$ of December) were assigned to the main plots, fertilization treatments $\left(\mathrm{T}_{1^{-}} 0.0\right.$ as control, $\mathrm{T}_{2^{-}}$ NPK recommended $\{65 \quad \mathrm{~kg} \quad \mathrm{~N}+150 \quad \mathrm{~kg}$ $\mathrm{P}_{2} \mathrm{O}_{5}+24 \mathrm{~kg} \mathrm{~K}_{2} \mathrm{O} /$ Faddan $\}, \mathrm{T}_{3}$ - Biofertilizer, $\mathrm{T}_{4^{-}}$Humic acid, $\mathrm{T}_{5-75 \%}$ of $\mathrm{NPK}+$ biofertilizer, $\mathrm{T}_{6}-50 \%$ of NPK + biofertilizer, $\mathrm{T}_{7^{-}} 25 \%$ of NPK + biofertilizer, $\mathrm{T}_{8^{-}} 75 \%$ of $\mathrm{NPK}+$ humic acid, $\mathrm{T}_{9^{-}} 50 \%$ of NPK + humic acid, $\mathrm{T}_{10^{-}}-25 \%$ of NPK + humic acid, $\mathrm{T}_{11^{-}} 75 \%$ of NPK + biofertilizer + humic acid, $\mathrm{T}_{12-}-50 \%$ of NPK + biofertilizer + humic acid, and $\mathrm{T}_{13^{-}}$ $50 \%$ of NPK + biofertilizer + humic acid) assign in sub plot. 


\subsection{Cultural practices}

The seeds were sowed on the $17^{\text {th }}$ of November in at rate of $60 \mathrm{~kg} /$ faddan in both seasons. Nitrogen fertilizer of urea $(46.5 \% \mathrm{~N})$ was applied in three doses, $20 \%$ at sowing, $40 \%$ before the first irrigation and the last $40 \%$ applied at the second irrigation. Superphosphate fertilizer $\left(15.5 \% \mathrm{P}_{2} \mathrm{O}_{5}\right)$ was applied before sowing. Potassium sulphate $\left(\begin{array}{lll}48 \% & \mathrm{~K}_{2} \mathrm{O}\end{array}\right)$ was applied during seedbed preparation. Nitrogen, phosphor, and potassium were applied as per treatment combination. Humic acid was added at rate of $2 \mathrm{~kg} /$ faddan on soil application after one month from sowing. Mixed bacterial biofertilizer containing nitrogen fixers (NFB, Azotobacter chroococcum and Azospirillum lipoferum), phosphate dissolving bacteria (PDB, Paenibacillus polymyxa and Bacillus polymyxa) and potassium dissolving bacteria (KDB, Bacillus cereus) was utilized in the present

study.

Table 1. Some physical and chemical properties of the experimental site in 2017/ 2018 and 2018/2019.

\begin{tabular}{|c|c|c|c|}
\hline \multicolumn{2}{|c|}{ Soil property } & $2017 / 2018$ & $2018 / 2019$ \\
\hline \multicolumn{2}{|c|}{ Sand $(\%)$} & 66.70 & 74 \\
\hline \multicolumn{2}{|l|}{ Silt $(\%)$} & 21.30 & 16.6 \\
\hline \multicolumn{2}{|l|}{ Clay $(\%)$} & 12 & 9.4 \\
\hline \multicolumn{2}{|c|}{ Soil texture } & Sandy loam & Sandy loam \\
\hline \multicolumn{2}{|c|}{ pH (1:1; Soil : Water suspension) } & 7.93 & 8.12 \\
\hline \multicolumn{2}{|c|}{ Organic matter $(\%)$} & 0.3 & 0.4 \\
\hline \multicolumn{2}{|c|}{$\mathrm{EC}\left(\mathrm{ds} \mathrm{m^{-1 } )}\right.$} & 9.95 & 4.62 \\
\hline \multicolumn{2}{|c|}{$\mathrm{CaCO} 3(\%)$} & 5.8 & 6.5 \\
\hline \multirow{3}{*}{ 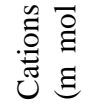 } & $\mathrm{K}+$ & 0.80 & 0.60 \\
\hline & $\mathrm{Ca}++$ & 11.5 & 9.5 \\
\hline & $\mathrm{Mg}++$ & 11.3 & 10.2 \\
\hline \multirow{3}{*}{ 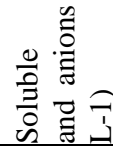 } & $\mathrm{HCO}-3$ & 20.00 & 16.00 \\
\hline & $\mathrm{Cl}-$ & 27.50 & 28.50 \\
\hline & SO--4 & 23.2 & 20.2 \\
\hline
\end{tabular}

Table 2. Minimum, maximum and mean daily temperature at South Valley University from sowing to harvesting date in both seasons.

\begin{tabular}{|c|c|c|c|c|c|c|c|}
\hline \multirow{3}{*}{ Month } & \multirow[t]{2}{*}{ Seasons } & \multicolumn{3}{|c|}{$2016 / 2017$} & \multicolumn{3}{|c|}{$2017 / 2018$} \\
\hline & & Mini. & Max. & $\begin{array}{l}\text { Daily } \\
\text { mean }\end{array}$ & Mini. & Max. & $\begin{array}{l}\text { Daily } \\
\text { mean }\end{array}$ \\
\hline & $1-15$ & 17.2 & 32.1 & 24.7 & 14.1 & 29.1 & 21.3 \\
\hline \multirow[t]{2}{*}{ Nov. } & $16-30$ & 14.6 & 27.5 & 21.0 & 13.7 & 26.6 & 19.8 \\
\hline & Mean & 15.9 & 29.8 & 22.9 & 13.9 & 27.9 & 20.9 \\
\hline \multirow{4}{*}{ Dec. } & $1-15$ & 9.8 & 22.9 & 16.4 & 11.7 & 26.0 & 18.5 \\
\hline & $16-31$ & 7.4 & 20.5 & 13.9 & 12.0 & 25.7 & 18.6 \\
\hline & Mean & 8.6 & 21.7 & 15.2 & 11.9 & 25.9 & 18.9 \\
\hline & $1-15$ & 6.2 & 20.9 & 13.5 & 8.2 & 22.9 & 15.3 \\
\hline \multirow{2}{*}{ Jan. } & $16-31$ & 9.1 & 23.0 & 16.0 & 7.3 & 21.5 & 14.4 \\
\hline & Mean & 7.7 & 22.0 & 14.9 & 7.8 & 22.2 & 15.0 \\
\hline \multirow{4}{*}{ Feb. } & $1-15$ & 8.4 & 32.0 & 15.7 & 8.4 & 23.0 & 15.7 \\
\hline & $16-28$ & 8.6 & 24.2 & 16.4 & 8.6 & 24.2 & 16.4 \\
\hline & Mean & 8.5 & 28.1 & 18.3 & 8.5 & 23.6 & 16.1 \\
\hline & $1-15$ & 13.3 & 27.6 & 20.0 & 15.7 & 33.1 & 24.3 \\
\hline \multirow{2}{*}{ March } & $16-31$ & 14.1 & 28.8 & 21.4 & 18.0 & 33.7 & 26.2 \\
\hline & Mean & 13.7 & 28.2 & 21.0 & 16.9 & 33.4 & 25.2 \\
\hline \multirow{3}{*}{ April } & $1-15$ & 18.7 & 33.2 & 25.9 & 18.7 & 34.2 & 26.7 \\
\hline & $16-30$ & 19.4 & 36.4 & 27.9 & 19.7 & 35.6 & 28.2 \\
\hline & Mean & 19.1 & 34.8 & 27.0 & 19.2 & 34.9 & 27.1 \\
\hline
\end{tabular}

Meteorological Authority at South Valley University, Qena 


\subsection{Measured traits}

At harvest time, ten plants were taken from each plot to measure the follow traits: Plant height $(\mathrm{cm})$, spike length $(\mathrm{cm})$, spike weight (g), 1000-grain weight $(\mathrm{g})$, grain yield/plant (g). The number of spikes $/ \mathrm{m}^{2}$ was calculated on one square meter. Grain and straw yields were estimated at plot basis.

\subsection{Statistical analysis}

The obtained data were subjected to analysis of variance according to Gomez and Gomez (1984) by MSTAT-C Computer program. Comparison between treatments means were done by least significant difference (LSD) procedures at $5 \%$ level of probability.

\section{Results and discussion}

\subsection{Plant height (cm)}

Plant height varied significantly $(\mathrm{p}<0.05)$ as affected by used sowing dates in the two seasons (Table 3 ). Medium sowing at $15^{\text {th }}$ of November surpassed the early $\left(1^{\text {st }}\right.$ of November) and late ( $1^{\text {st }}$ of December) sowing dates in this respect and gave the highest mean values of plant height in both seasons (83.89 and $81.58 \mathrm{~cm}$, respectively). Higher mean value of plant height under mid-November sown crop was reported by Rashid et al. (2010), Dastan et al. (2011), Pankaj et al. (2015a), Kumar et al. (2017) and Devi et al. (2018). Higher mean values of plant height under November 15 sowing were probably due to exposure of the crop to much desirable weather condition as compared to other dates as the temperature reduced sharply during December. Desirable sowing dates permitted the barley crop to grow under satisfactory temperature regime in various phonological stages of growth. Plant height was reduced to
10.83 and $2.68 \%$ under December 1 sowing against November 15 sowing in the first and second seasons, respectively. Delayed sowing to December exposed the crop to higher temperature and longer day length during elongation, which might have reduced the plant height. This decline in plant height with delayed sowing date was in conformity with the findings of Dastan et al. (2011), Pankaj et al. (2015b), Kumar et al. (2017), Devi et al. (2018) and Reddy and Singh (2018).

Data in Table 3 illustrated a significant $(\mathrm{p}<$ 0.05 ) effect of different treatment combinations of fertilization on plant height in the two growing seasons. The highest values for this trait were obtained by $\mathrm{T}_{11}(75 \% \mathrm{NPK}+$ biofertilization + humic acid) in both seasons. On the contrary, $\mathrm{T}_{1}$ (Control) had the shortest plants in the two seasons $(59.24$ and $59.01 \mathrm{~cm}$, respectively). It may be attributed due to the sufficient availability of plant nutrients like nitrogen, phosphorus and potassium to barley plant up to maturity (Kumar et al., 2013; Alazmani, 2015; Kouzegaran et al., 2015). Many workers noted the enhancing effect of humic acid on growth, yield, and nutrient uptake by many crops (El-Desuki, 2004; Wali et al., 2018).

Data in Table 3 indicates that there was significant effect of the interaction between sowing dates $\times$ fertilization treatments $(D \times T)$ on plant height in both seasons. Sowing at $15^{\text {th }}$ of November markedly improved plant height when $\mathrm{T}_{11}(75 \%$ NPK + biofertilization + humic acid) were used in both seasons. However, the shortest values of this character were obtained from the late sowing date $\left(D_{3}\right.$; $1^{\text {st }}$ of December) with $T_{1}$ (Without fertilization) at the two seasons. 
Table 3. Average plant height as affected by sowing dates and fertilization treatments and their interactions during 2016/2017 and 2017/2018 growing seasons.

\begin{tabular}{|c|c|c|c|c|c|c|c|c|}
\hline \multirow{3}{*}{$\begin{array}{c}\text { Fertilization } \\
\text { Treatment (T) }\end{array}$} & \multicolumn{3}{|c|}{$2016 / 2017$} & \multicolumn{5}{|c|}{$2017 / 2018$} \\
\hline & \multicolumn{3}{|c|}{ Sowing date (D) } & Mean & \multicolumn{3}{|c|}{ Sowing date (D) } & \multirow[t]{2}{*}{ Mean } \\
\hline & $\mathrm{D}_{1}$ & $\mathrm{D}_{2}$ & $\mathrm{D}_{3}$ & & $\mathrm{D}_{1}$ & $\mathrm{D}_{2}$ & $\mathrm{D}_{3}$ & \\
\hline $\mathrm{T}_{1}$ & 55.53 & 69.23 & 52.97 & 59.24 & 63.93 & 60.03 & 53.07 & 59.01 \\
\hline $\mathrm{T}_{2}$ & 79.73 & 89.37 & 79.87 & 82.99 & 91.13 & 91.47 & 90.07 & 90.89 \\
\hline $\mathrm{T}_{3}$ & 71.87 & 80.03 & 64.50 & 72.13 & 66.90 & 68.87 & 65.17 & 66.98 \\
\hline $\mathrm{T}_{4}$ & 73.17 & 82.90 & 69.37 & 75.15 & 65.37 & 67.47 & 63.77 & 65.54 \\
\hline $\mathrm{T}_{5}$ & 77.77 & 84.30 & 73.63 & 78.57 & 91.00 & 88.20 & 87.30 & 88.83 \\
\hline $\mathrm{T}_{6}$ & 75.27 & 83.20 & 75.47 & 77.98 & 77.70 & 83.10 & 86.53 & 82.44 \\
\hline $\mathrm{T}_{7}$ & 70.57 & 82.53 & 77.27 & 76.79 & 81.67 & 82.60 & 84.53 & 82.93 \\
\hline $\mathrm{T}_{8}$ & 78.03 & 83.20 & 76.37 & 79.20 & 87.13 & 87.87 & 81.03 & 85.34 \\
\hline $\mathrm{T}_{9}$ & 78.83 & 81.73 & 77.87 & 79.48 & 82.30 & 82.50 & 78.00 & 80.93 \\
\hline $\mathrm{T}_{10}$ & 73.97 & 79.27 & 76.53 & 76.59 & 82.30 & 77.23 & 73.07 & 77.53 \\
\hline $\mathrm{T}_{11}$ & 82.27 & 95.67 & 85.33 & 87.76 & 93.13 & 91.60 & 91.23 & 91.99 \\
\hline $\mathrm{T}_{12}$ & 79.53 & 86.47 & 78.90 & 81.63 & 91.07 & 91.63 & 92.37 & 91.69 \\
\hline $\mathrm{T}_{13}$ & 74.00 & 86.17 & 78.60 & 79.59 & 82.77 & 87.93 & 85.90 & 85.53 \\
\hline Mean & 74.66 & 83.39 & 74.36 & 77.47 & 81.26 & 81.58 & 79.39 & 80.74 \\
\hline \multirow[t]{2}{*}{$\mathrm{LSD}_{05}$} & $\mathrm{D}$ & $\mathrm{T}$ & $\mathrm{D} \times \mathrm{T}$ & & D & $\mathrm{T}$ & $\mathrm{D} \times \mathrm{T}$ & \\
\hline & 2.89 & 4.56 & 7.92 & & 1.67 & 2.82 & 4.88 & \\
\hline
\end{tabular}

\subsection{Number of spikes $/ \mathrm{m}^{2}$}

Data in Table 4 shows that sowing dates had significant influence on number of spikes $/ \mathrm{m}^{2}$ in both seasons. Number of spikes $/ \mathrm{m}^{2}$ was achieved under second sowing date $\left(15^{\text {th }}\right.$ of November) for 285.7 and 255.0, which was drastically reduced to 213.1 and 240.3 under late sowing date ( $1^{\text {st }}$ of December) in the first and second seasons, respectively. These results are in agreement with those obtained by Samarah and Al-Issa (2006), Singh et al. (2017) abd Devi et al. (2018).

Table 4. Average number of spikes $/ \mathrm{m}^{2}$ as affected by sowing dates, fertilization treatments and their interactions during 2016/2017 and 2017/2018 growing seasons.

\begin{tabular}{|c|c|c|c|c|c|c|c|c|}
\hline \multirow{3}{*}{$\begin{array}{c}\text { Fertilization } \\
\text { Treatment }(\mathrm{T})\end{array}$} & \multirow{2}{*}{\multicolumn{3}{|c|}{$\begin{array}{c}2016 / 2017 \\
\text { Sowing date (D) }\end{array}$}} & \multicolumn{5}{|c|}{$2017 / 2018$} \\
\hline & & & & \multirow[t]{2}{*}{ Mean } & \multicolumn{3}{|c|}{ Sowing date (D) } & \multirow[t]{2}{*}{ Mean } \\
\hline & $\mathrm{D}_{1}$ & $\mathrm{D}_{2}$ & $\mathrm{D}_{3}$ & & $\mathrm{D}_{1}$ & $\mathrm{D}_{2}$ & $\mathrm{D}_{3}$ & \\
\hline $\mathrm{T}_{1}$ & 192.8 & 174.2 & 143.8 & 170.3 & 178.8 & 160.0 & 143.0 & 160.6 \\
\hline $\mathrm{T}_{2}$ & 340.0 & 339.7 & 242.8 & 307.5 & 295.5 & 298.0 & 276.7 & 290.1 \\
\hline $\mathrm{T}_{3}$ & 240.0 & 250.0 & 169.8 & 219.9 & 220.3 & 187.3 & 182.7 & 196.8 \\
\hline $\mathrm{T}_{4}$ & 230.3 & 218.5 & 163.2 & 204.0 & 238.5 & 238.2 & 226.7 & 234.5 \\
\hline $\mathrm{T}_{5}$ & 310.0 & 309.8 & 224.5 & 281.4 & 264.0 & 268.0 & 261.3 & 264.4 \\
\hline $\mathrm{T}_{6}$ & 291.5 & 299.0 & 219.0 & 269.8 & 235.0 & 254.3 & 243.3 & 244.2 \\
\hline $\mathrm{T}_{7}$ & 279.7 & 285.2 & 223.3 & 262.7 & 242.5 & 263.2 & 256.3 & 254.0 \\
\hline $\mathrm{T}_{8}$ & 278.5 & 265.7 & 215.0 & 253.1 & 272.0 & 264.2 & 259.2 & 265.1 \\
\hline $\mathrm{T}_{9}$ & 278.7 & 276.2 & 224.2 & 259.7 & 251.0 & 246.5 & 225.0 & 240.8 \\
\hline $\mathrm{T}_{10}$ & 252.7 & 279.2 & 202.0 & 244.6 & 229.5 & 260.2 & 230.8 & 240.2 \\
\hline $\mathrm{T}_{11}$ & 369.3 & 380.0 & 254.8 & 334.7 & 299.0 & 321.3 & 277.3 & 299.2 \\
\hline $\mathrm{T}_{12}$ & 314.2 & 326.3 & 251.3 & 297.3 & 281.2 & 287.5 & 274.5 & 281.1 \\
\hline $\mathrm{T}_{13}$ & 292.0 & 310.3 & 236.8 & 279.7 & 253.7 & 265.8 & 267.3 & 262.3 \\
\hline Mean & 282.3 & 285.7 & 213.1 & 260.4 & 250.8 & 255.0 & 240.3 & 248.7 \\
\hline \multirow[t]{2}{*}{$\mathrm{LSD}_{05}$} & D & $\mathrm{T}$ & $\mathrm{D} \times \mathrm{T}$ & & D & $\mathrm{T}$ & $\mathrm{D} \times \mathrm{T}$ & \\
\hline & 34.2 & 39.1 & 67.7 & & 10.7 & 18.1 & 31.3 & \\
\hline
\end{tabular}

Different treatment combinations of fertilization had a significant influence on number of spikes $/ \mathrm{m}^{2}$ (Table 4). The highest number of spikes $/ \mathrm{m}^{2}$ (334.7 and 299.2 in the first and second seasons, respectively) was obtained by $T_{11}$. Nevertheless, the lowest 
values of number of spikes $/ \mathrm{m}^{2}$ obtained from $\mathrm{T}_{1}$ as control in both seasons (170.3 and 160.6, respectively). Similar results were obtained by El-Desuki (2004) and Wali et al. (2018).

Sowing dates $\times$ fertilization treatments gave significant influence on number of spikes $/ \mathrm{m}^{2}$ (Table 4). The highest number of spikes $/ \mathrm{m}^{2}$ (380.0 and 321.3 in the first and second seasons, respectively) was produced from $\mathrm{D}_{2} \times$ $\mathrm{T}_{11}$ in both seasons. The lowest number of spikes $/ \mathrm{m}^{2}$ was recorded under $\mathrm{D}_{3} \times \mathrm{T}_{1}(143.8$ and 143.0 in the first and second seasons, respectively). The results are in agreement with the findings of Baladezaie et al. (2011) and Reddy and Singh (2018).

\subsection{Spike length}

Spike length varied significantly $(\mathrm{P}<0.05)$ as affected by studied sowing dates in the two growing seasons (Table 5). Sowing date at $15^{\text {th }}$ of November surpassed the two other dates in this respect and gained the longest mean values of spike length (17.33 and $17.05 \mathrm{~cm}$ in the first and second seasons, respectively). Spike length was at par between other different sowing dates (early and late sowing dates). Spike length was decreased to 7.04 and $3.23 \%$ under late date ( $1^{\text {st }}$ of December) against medium date ( $15^{\text {th }}$ of November) in the first and second seasons, respectively.

Table 5. Average spike length as affected by sowing dates, fertilization treatments and their interactions during 2016/2017 and 2017/2018 growing seasons.

\begin{tabular}{|c|c|c|c|c|c|c|c|c|}
\hline \multirow{3}{*}{$\begin{array}{l}\text { Fertilization } \\
\text { Treatment }(\mathrm{T})\end{array}$} & \multicolumn{3}{|c|}{$2016 / 2017$} & \multicolumn{5}{|c|}{$2017 / 2018$} \\
\hline & \multicolumn{3}{|c|}{ Sowing date (D) } & \multirow[t]{2}{*}{ Mean } & \multicolumn{3}{|c|}{ Sowing date (D) } & \multirow[t]{2}{*}{ Mean } \\
\hline & $\mathrm{D}_{1}$ & $\mathrm{D}_{2}$ & $\mathrm{D}_{3}$ & & $\mathrm{D}_{1}$ & $\mathrm{D}_{2}$ & $\mathrm{D}_{3}$ & \\
\hline $\mathrm{T}_{2}$ & 16.73 & 18.07 & 17.13 & 17.31 & 17.73 & 17.93 & 17.83 & 17.83 \\
\hline $\mathrm{T}_{3}$ & 16.13 & 16.73 & 16.00 & 16.29 & 15.47 & 15.60 & 15.70 & 15.59 \\
\hline $\mathrm{T}_{6}$ & 16.07 & 16.73 & 16.00 & 16.27 & 17.20 & 17.60 & 15.70 & 16.83 \\
\hline $\mathrm{T}_{7}$ & 16.20 & 17.37 & 15.90 & 16.49 & 16.60 & 17.17 & 16.80 & 16.86 \\
\hline $\mathrm{T}_{8}$ & 16.53 & 17.50 & 16.73 & 16.92 & 16.93 & 17.80 & 17.33 & 17.35 \\
\hline $\mathrm{T}_{9}$ & 16.23 & 17.40 & 16.13 & 16.59 & 16.73 & 17.30 & 16.10 & 16.71 \\
\hline $\mathrm{T}_{10}$ & 14.30 & 17.20 & 15.93 & 15.81 & 16.60 & 17.70 & 17.07 & 17.12 \\
\hline Mean & 16.17 & 17.33 & 16.11 & 16.54 & 16.79 & 17.05 & 16.50 & 16.78 \\
\hline \multirow{2}{*}{$\mathrm{LSD}_{05}$} & D & $\mathrm{T}$ & $\mathrm{D} \times \mathrm{T}$ & & $\mathrm{D}$ & $\mathrm{T}$ & $\mathrm{D} \times \mathrm{T}$ & \\
\hline & 0.54 & 0.72 & 1.26 & & 0.34 & 0.64 & 1.10 & \\
\hline
\end{tabular}

The differential behavior or length of spike due to different sowing date might be explained by the fact that sowing during higher temperature, the plant could not get congenial environment for growth and development affecting development of spike. Devi et al. (2018) stated that the spike length was at par among different sowing dates.

Data in Table 5 illustrated significant $(\mathrm{P}<$ 0.05 ) effect of treatment combinations of fertilization on spike length in both growing seasons. The longest values (17.94 and 18.07 $\mathrm{cm}$ in the first and second seasons, respectively) of mentioned trait were recorded by $\mathrm{T}_{11}$. On the contrary, $\mathrm{T}_{1}$ (Control) recorded the lowest values $(14.12$ and $13.75 \mathrm{~cm}$ in the first and second seasons, respectively) for this trait. Similar results were obtained by Kumar et al. (2017) and Wali et al. (2018).

Moreover, data in Table 5 focused that the interaction between sowing dates and fertilization treatments had a significant influence of spike length in both seasons. $\mathrm{D}_{2} \times$ $\mathrm{T}_{11}$ gained the significant $(\mathrm{P}<0.05)$ maximum values of spike length $(18.87$ and $18.50 \mathrm{~cm}$ in the first and second seasons, respectively). The 
lowest spike length $(12.93$ and $13.37 \mathrm{~cm})$ was obtained from $\mathrm{D}_{3} \times \mathrm{T}_{1}$ in the first and second seasons, respectively. Similar findings were also reported by Narolia et al. (2013) and Reddy and Singh (2018).

\subsection{Spike weight}

Data in Table 6 shows that the sowing dates had a significant effect on spike weight in both seasons. Sowing under $15^{\text {th }}$ of November had the highest mean values of spike weight (2.303 and $1.992 \mathrm{~g}$ in both seasons, respectively) compared to other dates. The late sowing date ( $1^{\text {st }}$ of December) was reduced spike weight by 11.38 and $14.16 \%$ against medium sowing date $\left(15^{\text {th }}\right.$ of November) in the first and second seasons, respectively.

As for treatment combinations of fertilization, these treatments affected significantly the spike weight in both seasons. Results in Table 6 indicate that the $T_{11}$ surpassed all other treatment combinations of fertilization in both seasons. On the other hand, $\mathrm{T}_{1}$ gave the lowest spike weight $(0.890$ and $0.653 \mathrm{~g}$ in the first and second seasons, respectively). Similar findings were also reported by El-Desuki (2004) and Wali et al. (2018).

Regarding the effect of the interaction between sowing dates and fertilization treatments $(\mathrm{D} \times$ $\mathrm{T})$, this interaction was significant on spike weight in both seasons. Application of $\mathrm{T}_{1}$ markedly decreased spike weight when sown at late date $\left(1^{\text {st }}\right.$ of December) in both seasons. But the highest spike weight (3.083 and 2.568 g) recorded when addition of $T_{11}$ and sown under medium sowing date ( $15^{\text {th }}$ of November) in both seasons.

Table 6. Average spike weight as affected by sowing dates, fertilization treatments and their interactions during 2016/2017 and 2017/2018 growing seasons.

\begin{tabular}{|c|c|c|c|c|c|c|c|c|}
\hline \multirow{3}{*}{$\begin{array}{c}\text { Fertilization } \\
\text { Treatment } \\
\text { (T) }\end{array}$} & \multirow{2}{*}{\multicolumn{3}{|c|}{$\begin{array}{c}2016 / 2017 \\
\text { Sowing date (D) }\end{array}$}} & \multicolumn{5}{|c|}{$2017 / 2018$} \\
\hline & & & & \multirow{2}{*}{ Mean } & \multicolumn{3}{|c|}{ Sowing date $(\mathrm{D})$} & \multirow[t]{2}{*}{ Mean } \\
\hline & $\mathrm{D}_{1}$ & $\mathrm{D}_{2}$ & $\mathrm{D}_{3}$ & & $\mathrm{D}_{1}$ & $\mathrm{D}_{2}$ & $\mathrm{D}_{3}$ & \\
\hline $\mathrm{T}_{1}$ & 1.483 & 0.963 & 0.890 & 1.112 & 0.760 & 0.650 & 0.550 & 0.653 \\
\hline $\mathrm{T}_{2}$ & 2.480 & 2.780 & 2.257 & 2.506 & 2.173 & 2.336 & 2.175 & 2.228 \\
\hline $\mathrm{T}_{3}$ & 1.890 & 1.527 & 1.930 & 1.782 & 1.601 & 1.328 & 1.152 & 1.360 \\
\hline $\mathrm{T}_{4}$ & 2.043 & 1.870 & 1.743 & 1.885 & 1.380 & 1.339 & 1.267 & 1.329 \\
\hline $\mathrm{T}_{5}$ & 2.320 & 2.440 & 2.063 & 2.274 & 2.094 & 2.152 & 1.93 & 2.059 \\
\hline $\mathrm{T}_{6}$ & 2.023 & 2.153 & 1.983 & 2.053 & 1.755 & 1.776 & 1.944 & 1.825 \\
\hline $\mathrm{T}_{7}$ & 2.223 & 2.193 & 1.960 & 2.125 & 1.605 & 2.186 & 1.784 & 1.858 \\
\hline $\mathrm{T}_{8}$ & 2.410 & 2.363 & 2.147 & 2.307 & 2.087 & 2.217 & 1.965 & 2.090 \\
\hline $\mathrm{T}_{9}$ & 2.013 & 2.317 & 2.110 & 2.147 & 1.823 & 2.351 & 1.738 & 1.971 \\
\hline $\mathrm{T}_{10}$ & 2.297 & 2.537 & 1.957 & 2.264 & 1.942 & 2.257 & 1.323 & 1.841 \\
\hline $\mathrm{T}_{11}$ & 2.570 & 3.083 & 2.923 & 2.859 & 2.345 & 2.568 & 2.434 & 2.449 \\
\hline $\mathrm{T}_{12}$ & 2.493 & 3.013 & 2.487 & 2.664 & 2.197 & 2.435 & 2.069 & 2.234 \\
\hline $\mathrm{T}_{13}$ & 2.443 & 2.700 & 2.077 & 2.407 & 1.974 & 2.298 & 1.905 & 2.059 \\
\hline Mean & 2.207 & 2.303 & 2.041 & 2.183 & 1.826 & 1.992 & 1.710 & 1.843 \\
\hline \multirow[t]{2}{*}{$\mathrm{LSD}_{05}$} & $\mathrm{D}$ & $\mathrm{T}$ & $\mathrm{D} \times \mathrm{T}$ & & D & $\mathrm{T}$ & $\mathrm{D} \times \mathrm{T}$ & \\
\hline & 0.189 & 0.316 & 0.544 & & 0.245 & 0.280 & 0.520 & \\
\hline
\end{tabular}

\subsection{0-grain weight}

Data in Table 7 reveals that the sowing dates had a significant effect on 1000-grain weight in both seasons. Heaviest 1000-grain weight was observed in November 15 sowing which was significantly heavier than December 1 but statistically at par with November 1 in $2016 / 2017$ but in 2017/2018, it was significantly heavier than November 1 and
December 1 sowing. Moreover, sowing date at $1^{\text {st }}$ of December was reduced 1000-grain weight by 3.71 and $5.20 \%$ against sowing date at $15^{\text {th }}$ of November in the first and second seasons, respectively. Similar results were reported by Datsan et al. (2011), Singh et al. (2017), Devi et al. (2018) and Reddy and Singh (2018). 
Table 7. Average 1000-grain weight as affected by sowing dates, fertilization treatments and their interactions during 2016/2017 and 2017/2018 growing seasons.

\begin{tabular}{|c|c|c|c|c|c|c|c|c|}
\hline \multirow{2}{*}{$\begin{array}{c}\text { Fertilization } \\
\text { Treatment (T) }\end{array}$} & \multicolumn{3}{|c|}{$2016 / 2017$} & \multicolumn{5}{|c|}{$2017 / 2018$} \\
\hline & \multicolumn{3}{|c|}{ Sowing date (D) } & Mean & \multicolumn{3}{|c|}{ Sowing date (D) } & \multirow[t]{2}{*}{ Mean } \\
\hline & $\mathrm{D}_{1}$ & $\mathrm{D}_{2}$ & $\mathrm{D}_{3}$ & & $\mathrm{D}_{1}$ & $\mathrm{D}_{2}$ & $\mathrm{D}_{3}$ & \\
\hline $\mathrm{T}_{1}$ & 48.14 & 48.98 & 45.60 & 47.57 & 46.03 & 50.00 & 45.29 & 47.11 \\
\hline $\mathrm{T}_{2}$ & 52.93 & 53.50 & 52.49 & 52.97 & 57.06 & 57.90 & 54.91 & 56.62 \\
\hline $\mathrm{T}_{3}$ & 51.30 & 51.17 & 50.46 & 50.98 & 55.16 & 50.59 & 50.31 & 52.02 \\
\hline $\mathrm{T}_{4}$ & 51.73 & 50.78 & 48.63 & 50.38 & 52.74 & 54.88 & 50.91 & 52.84 \\
\hline $\mathrm{T}_{5}$ & 52.83 & 52.59 & 50.28 & 51.90 & 56.01 & 56.16 & 54.47 & 55.55 \\
\hline $\mathrm{T}_{6}$ & 51.86 & 52.26 & 50.47 & 51.53 & 54.47 & 52.71 & 49.17 & 52.12 \\
\hline $\mathrm{T}_{7}$ & 51.99 & 51.01 & 48.32 & 50.44 & 51.47 & 51.95 & 50.86 & 51.43 \\
\hline $\mathrm{T}_{8}$ & 51.85 & 52.75 & 51.30 & 51.97 & 55.08 & 55.96 & 53.57 & 54.87 \\
\hline $\mathrm{T}_{9}$ & 51.79 & 52.35 & 51.61 & 51.92 & 51.52 & 55.35 & 52.42 & 53.10 \\
\hline $\mathrm{T}_{10}$ & 48.40 & 51.67 & 49.19 & 49.75 & 50.77 & 52.93 & 48.87 & 50.86 \\
\hline $\mathrm{T}_{11}$ & 54.39 & 56.18 & 52.79 & 54.45 & 59.23 & 62.91 & 58.25 & 60.13 \\
\hline $\mathrm{T}_{12}$ & 53.51 & 53.80 & 51.98 & 53.10 & 56.57 & 58.89 & 57.79 & 57.75 \\
\hline $\mathrm{T}_{13}$ & 52.83 & 53.21 & 51.92 & 52.65 & 55.95 & 57.13 & 53.19 & 55.42 \\
\hline Mean & 51.81 & 52.33 & 50.39 & 51.51 & 54.00 & 55.18 & 52.31 & 53.83 \\
\hline $\mathrm{LSD}_{05}$ & $\mathrm{D}$ & $\mathrm{T}$ & $\mathrm{D} \times \mathrm{T}$ & & $\mathrm{D}$ & $\mathrm{T}$ & $\mathrm{D} \times \mathrm{T}$ & \\
\hline & 1.20 & 1.70 & 2.96 & & 2.08 & 2.54 & 4.40 & \\
\hline
\end{tabular}

As for treatment combinations of fertilization, these treatments affected significantly the 1000 -grain weight in both seasons. Results in Table 7 indicate that the $T_{11}$ surpassed all other treatment combinations of fertilization in both seasons. On the other hand, $\mathrm{T}_{1}$ gave the lightest 1000-grain weight (47.57 and $47.11 \mathrm{~g}$ in the first and second seasons, respectively). It may be attributed due to the use of phosphorus solubilizing bacteria as inoculants increases P uptake. Similar findings were also reported Datsan et al. (2011), Singh et al. (2017), Kumar et al. (2017), Devi et al. (2018) and Wali et al. (2018).

Respecting the effect of the interaction between sowing dates and fertilization treatments $(\mathrm{D} \times \mathrm{T})$, this interaction was significant on 1000-grain weight in both seasons (Table 7). Application of $\mathrm{T}_{1}$ markedly decreased 1000-grain weight when sown at late sowing date $\left(1^{\text {st }}\right.$ of December) in both seasons. But the heaviest 1000-grain weight (56.18 and $62.91 \mathrm{~g}$ in the first and second seasons, respectively) was recorded when addition of $\mathrm{T}_{11}$ and sown under medium sowing date $\left(15^{\text {th }}\right.$ of November). Similar findings were also reported by Datsan et al. (2011), Tripathi et al. (2013) and Reddy and Singh (2018).

\subsection{Grain yield (Ard./fad.)}

Data in Table 8 shows that crop sown under November 8 recorded the highest grain yield of 14.23 and 11.96 Ard./fad., which 28.88 and $7.78 \%$ higher than the crop was sown under late (December 1) condition in the first and second seasons, respectively. The higher yield in timely sowing condition could be attributed to favorable temperature at grain development stage which in turn increased the photosynthetic rate, assimilates the supply for seed and seed growth rate in timely sown crops. Higher grain yield of barley under timely sown condition as compared to other sowing dates of barley was also reported by a number of workers (Singh et al., 2017; Devi et al., 2018; Reddy and Singh, 2018).

Grain yield of barley was significantly influenced by the application of NPK, biofertilizers and humic acid (Table 8). Among the different treatment combination of fertilization, $\mathrm{T}_{11}$ gave the highest yielder (17.67 and 15.47 Ard/faddan in the first and second seasons, respectively). Whereas the lowest values (5.90 and 5.65 Ard/fed.) of this trait was observed from treated with $\mathrm{T}_{1}$ (Control) in both seasons, respectively. It may be increased due to the more availability of plant nutrients at all growth stages and 
application of biofertilizer and humic acid significantly seed set and seed filling efficiency (Safina, 2010, Ekin, 2010; Kumar et al., 2017; Wali et al., 2018).

There was a significant effect of the interaction between sowing dates and fertilization treatments on grain yield/fed in both seasons (Table 8). The highest grain yield (18.95 and 16.34 Ard./fed. in the first and second seasons, respectively) was recorded under sowing at $15^{\text {th }}$ of November and applied of $75 \%$ NPK + biofertilization + humic acid. However, the lowest grain yield (4.25 and 3.85 Ard/faddan) was registered from $\mathrm{D}_{3} \times \mathrm{T}_{1}$ in the first and second seasons, respectively. It might be due to cumulative effect of growth and yield attributing characters owing to fertilization. Greater availability of metabolites (Phosphosynthates) and nutrients to developing reproductive structures seems to have resulted in increase in all the yieldattributing characters which ultimately improved the yield of the crop Singh et al. (2010). Similar findings were reported by Dastan et al. (2011), Mukherjee et al. (2012), Meena et al. (2012), Singh et al. (2013) and Reddy and Singh (2018).

Table 8. Average grain yield (Ardab/ feddan) as affected by sowing dates, fertilization treatments and their interactions during 2016/2017 and 2017/2018 growing seasons.

\begin{tabular}{|c|c|c|c|c|c|c|c|c|}
\hline \multirow{3}{*}{$\begin{array}{l}\text { Fertilization } \\
\text { Treatment (T) }\end{array}$} & \multirow{2}{*}{\multicolumn{3}{|c|}{$\begin{array}{c}2016 / 2017 \\
\text { Sowing date (D) }\end{array}$}} & \multicolumn{5}{|c|}{$2017 / 2018$} \\
\hline & & & & \multirow[t]{2}{*}{ Mean } & \multicolumn{3}{|c|}{ Sowing date (D) } & \multirow[t]{2}{*}{ Mean } \\
\hline & $D_{1}$ & $\mathrm{D}_{2}$ & $D_{3}$ & & $D_{1}$ & $\mathrm{D}_{2}$ & $D_{3}$ & \\
\hline $\mathrm{T}_{1}$ & 4.88 & 8.58 & 4.25 & 5.90 & 6.53 & 6.57 & 3.85 & 5.65 \\
\hline $\mathrm{T}_{2}$ & 15.75 & 17.15 & 13.49 & 15.46 & 14.49 & 15.50 & 13.95 & 14.65 \\
\hline $\mathrm{T}_{3}$ & 10.51 & 11.35 & 6.13 & 9.33 & 8.54 & 6.86 & 4.97 & 6.79 \\
\hline $\mathrm{T}_{4}$ & 10.29 & 13.88 & 6.31 & 10.16 & 7.96 & 10.09 & 8.03 & 8.69 \\
\hline $\mathrm{T}_{5}$ & 15.67 & 15.89 & 10.64 & 14.07 & 12.58 & 13.13 & 12.26 & 12.66 \\
\hline $\mathrm{T}_{6}$ & 14.93 & 15.34 & 9.18 & 13.15 & 10.96 & 11.63 & 13.21 & 11.93 \\
\hline $\mathrm{T}_{7}$ & 13.44 & 12.76 & 10.91 & 12.37 & 11.60 & 11.34 & 11.62 & 11.52 \\
\hline $\mathrm{T}_{8}$ & 15.12 & 14.34 & 11.89 & 13.78 & 11.23 & 14.58 & 13.32 & 13.04 \\
\hline $\mathrm{T}_{9}$ & 14.06 & 12.89 & 11.78 & 12.91 & 12.44 & 12.35 & 11.59 & 12.13 \\
\hline $\mathrm{T}_{10}$ & 14.31 & 13.65 & 8.72 & 12.23 & 8.50 & 10.13 & 8.73 & 9.12 \\
\hline $\mathrm{T}_{11}$ & 19.11 & 18.95 & 14.96 & 17.67 & 15.28 & 16.34 & 14.78 & 15.47 \\
\hline $\mathrm{T}_{12}$ & 16.33 & 16.06 & 12.61 & 15.00 & 13.22 & 15.00 & 13.81 & 14.01 \\
\hline $\mathrm{T}_{13}$ & 14.74 & 14.16 & 10.73 & 13.21 & 12.11 & 11.91 & 13.24 & 12.42 \\
\hline Mean & 13.78 & 14.23 & 10.12 & 12.71 & 11.19 & 11.96 & 11.03 & 11.39 \\
\hline \multirow[t]{2}{*}{$\mathrm{LSD}_{05}$} & $\mathrm{D}$ & $\mathrm{T}$ & $\mathrm{D} \times \mathrm{T}$ & & D & $\mathrm{T}$ & $\mathrm{D} \times \mathrm{T}$ & \\
\hline & 2.28 & 2.20 & 3.80 & & 0.64 & 0.98 & 1.68 & \\
\hline
\end{tabular}

\subsection{Straw yield/faddan}

The presented data in Table 9 reveal that the studied sowing dates had a significant effect on straw yield/feddan of barely plants in both seasons. Thus, the highest mean values of straw yield/fed.; 2824.5 and $4249.3 \mathrm{~kg} /$ feddan were obtained from barely plants, which were sown under medium sowing date $\left(15^{\text {th }}\right.$ of November) in the first and second seasons. The significant response of straw yield/feddan could attribute to their essential roles in plant growth. The results are in accordance with those of Chaudhary et al. (2017) and Devi et al. (2018).

Results in Table 9 point out a significant effect on straw yield/feddan due to treatment combinations of fertilization in both seasons. The application of $T_{11}$ gave the highest values of straw yield/feddan (3386.2 and 4816.6 $\mathrm{kg} /$ feddan in the first and second seasons, respectively). It may be attributed due to the maximum number of tillers plant ${ }^{-1}$; optimum plant height and no crop lodging were found the treatment (Ekin, 2010 and Kumar et al., 2013). 
Table 9. Average straw yield ( $\mathrm{kg} /$ feddan) as affected by sowing dates, fertilization treatments and their interactions during 2016/2017 and 2017/2018 growing seasons.

\begin{tabular}{|c|c|c|c|c|c|c|c|c|}
\hline \multirow{3}{*}{$\begin{array}{c}\text { Fertilization } \\
\text { Treatment (T) }\end{array}$} & \multicolumn{3}{|c|}{$2016 / 2017$} & \multicolumn{5}{|c|}{$2017 / 2018$} \\
\hline & \multicolumn{3}{|c|}{ Sowing date (D) } & \multirow[t]{2}{*}{ Mean } & \multicolumn{3}{|c|}{ Sowing date (D) } & \multirow[t]{2}{*}{ Mean } \\
\hline & $\mathrm{D}_{1}$ & $\mathrm{D}_{2}$ & $\mathrm{D}_{3}$ & & $\mathrm{D}_{1}$ & $\mathrm{D}_{2}$ & $\mathrm{D}_{3}$ & \\
\hline $\mathrm{T}_{1}$ & 1940.7 & 1330.0 & 1278.0 & 1516.2 & 1223.3 & 2975.3 & 934.0 & 1710.9 \\
\hline $\mathrm{T}_{2}$ & 2842.7 & 3460.0 & 2617.3 & 2973.3 & 3493.3 & 4935.3 & 3048.0 & 3825.5 \\
\hline $\mathrm{T}_{3}$ & 2189.3 & 1766.0 & 1564.0 & 1839.8 & 1766.0 & 3646.7 & 1187.3 & 2200.0 \\
\hline $\mathrm{T}_{4}$ & 1984.7 & 2197.3 & 2308.7 & 2163.6 & 2197.3 & 3325.3 & 1815.3 & 2446.0 \\
\hline $\mathrm{T}_{5}$ & 2770.0 & 2995.3 & 2433.3 & 2732.9 & 2995.3 & 4170.0 & 2476.0 & 3213.8 \\
\hline $\mathrm{T}_{6}$ & 2428.7 & 2864.0 & 2408.0 & 2566.9 & 2864.0 & 4011.3 & 2412.7 & 3096.0 \\
\hline $\mathrm{T}_{7}$ & 2356.7 & 2672.0 & 2246.7 & 2425.1 & 2672.0 & 3947.3 & 1792.7 & 2804.0 \\
\hline $\mathrm{T}_{8}$ & 2640.0 & 3110.0 & 2410.0 & 2720.0 & 3110.0 & 4804.0 & 2793.3 & 3569.1 \\
\hline $\mathrm{T}_{9}$ & 2331.3 & 3067.7 & 2309.3 & 2569.4 & 3068.0 & 4594.0 & 2662.7 & 3441.6 \\
\hline $\mathrm{T}_{10}$ & 2292.0 & 2924.7 & 2494.0 & 2570.2 & 2924.7 & 4086.7 & 2558.0 & 3189.8 \\
\hline $\mathrm{T}_{11}$ & 3230.7 & 3906.7 & 3021.3 & 3386.2 & 4673.3 & 5733.3 & 4043.3 & 4816.6 \\
\hline $\mathrm{T}_{12}$ & 2854.7 & 3440.0 & 2908.0 & 3067.6 & 3440.0 & 4843.3 & 3369.3 & 3884.2 \\
\hline $\mathrm{T}_{13}$ & 2543.3 & 2984.7 & 2540.0 & 2689.3 & 3284.7 & 4168.7 & 2569.3 & 3340.9 \\
\hline Mean & 2492.7 & 2824.5 & 2349.1 & 2555.4 & 2900.9 & 4249.3 & 2435.5 & 3195.3 \\
\hline $\mathrm{LSD}_{05}$ & D & $\mathrm{T}$ & $\mathrm{D} \times \mathrm{T}$ & & D & $\mathrm{T}$ & $\mathrm{D} \times \mathrm{T}$ & \\
\hline & 316.6 & 463.9 & 803.5 & & 466.6 & 596.2 & 1032.7 & \\
\hline
\end{tabular}

The results are in accordance with those of Meena et al. (2011), El-Bassiouny et al. (2014), Kumar et al. (2017), Wali et al. (2018) and Karima-Ahmed and Hassan (2019).

Moreover, the interaction between sowing dates and treatment combinations of fertilization $(\mathrm{D} \times \mathrm{T})$ had a significant effect on the straw yield/feddan in the two growing seasons (Table 9). The highest mean values of straw yield/feddan (3906.7 and 5733.3 $\mathrm{kg} / \mathrm{feddan}$ in the first and second seasons, respectively) were obtained from $\mathrm{D}_{2} \times \mathrm{T}_{11}$. The significant response can be attributing to a different trend of response, which was observed in plants application fertilization type under favorable sowing date. Similar results were obtained by Reddy and Singh (2018).

\section{References}

Abd El-Lattief, E. A. 2014. Influence of integrated nutrient management on productivity and grain protein content of wheat under sandy soils conditions. Biolife, 2(4): 1359-1364.

Al Myali, A. A. H.; A. S. Hassoon and A. A. K. Alaameri, 2020. Effect of variety and planting date on growth and yield of barley (Hordeum vulgare L.). Plant Archives, 20(1): 355-358.
Alazmani, A. 2015. Evaluation of yield and yieldcomponents of barley varieties to nitrogen. International Journal of agriculture and crop sciences, 8-1/5254.

Al-Otayk, S. M. 2009. Impact of biofertilizers application on improving barley (Hordeum vulgare) and the presence of dehydrin genes. Middle East and Russian Journal of Plant Science and Biotechnology, 3(1): 58-61.

Amarjeet; B. Singh; J. Kumar; M. Kumar; R. Sharma and P.Kaushik, 2020. Effect of sowing date, seed rate and row spacing on productivity and profitability of barley (Hordeum vulgare $L)$ in north India. doi:10.20944/preprints202001.0380.v 1

Baladezaie, R. R.; N. A. Nemati; H. R. Mobasser; G. A. Malidarreh and S. Dastan, 2011. Effects of sowing dates and CCC application on yield and yield components of barley (Hordeum vulgare $L$.) cultivars in the north of Iran. American Eurasian J. Agric. \& Environ. Sci., 11(1): 49-54. 
Bavei, V. and B. Vaezi, 2012. Effect of late planting heat stress on yield, yield components and tolerance indices in barley (Hordeum vulgare L.). Iranian Journal of Field Crop Science, 43(3): 405-420.

Chaudhary, A.; M. Sewhag; V. S. Hooda; B. Singh and K. Parveen, 2017. Effect of different dates of sowing on yield attributes, yield and quality of Barley (Hordeum vulgare L.). Journal of Applied and Natural Science, 9(1): 129-132.

Dastan, H. R; M. A. Ghanbari-Malidarreh; R. Arab; E. Ghorbannia and R. Rahimi, 2011. Effects of sowing dates and CCC application on morphological traits, agronomical indices and grain yield in barley cultivars. World Applied Sciences Journal, 14 (11): 1717-1723.

Devi, K. P.; B. Mitra; T. PAUL; S. Das; S. S. Roy and A. K. S. Roy, 2018. Evaluation of barley (Hordeum vulgare $L$.) cultivars under different dates of sowing in terai zone of West Bengal. Journal of Crop and Weed, 14(1): 185-187.

Ekin, Z., 2010. Performance of phosphate solubilizing bacteria for improving growth and yield of sunflower (Helianthus annuus L.) in the presence of phosphorus fertilizer, African Journal of Biotechnology, 9 (25): 3794-3800.

El-Bassiouny, H. S. M.; A. B. Bakry; A. A. Abd El-Monem and M. M. Abd Allah, 2014. Physiological role of humic acid and nicotinamide on improving plant growth, yield, and mineral nutrient of wheat (Triticum durum) grown under newly reclaimed sandy soil. Agricultural Sciences, 5: 687-700.

El-Desuki, M., 2004. Response of onion plants to humic acid and mineral fertilizers application. Annals of Agric. Sci., Moshtohor, 42(4): 1955-1964.

Gaur, V. 2010. Biofertilizer-Necessity for sustainability. J. Adv. Dev., 1: 7-8.

Goel, A. K.; R. D. S. Laura; P. G. Anuradha and A. Goel, 1999. Use biofertilizers potential, constraints abd future strategies review. Int. J. Trop. Agric., 17: $1-8$.

Gomez, K. A., and A. A. Gomez, 1984. Statistical Procedures for Agricultural Research. John Wiley\& Sons Inc. New York, USA.

Helmy, A. M.; M. K. Abdel Fattah and K. A. Shaban, 2013. Nitrogen effeciency in barely under saline- sodicconditionds as affected by urea, compost and bio fertilizer (Rhizobium radiobacter sp.). Journal of Soil Science and Agricultural Engineering, 4(11): 11691189.

Karima R. Ahmed and A.M.A. Hassan, 2019. Effect of planting method on barley productivity, water saving and nutrient use efficiency under El-Minia conditions. Middle East J. Agric. Res., 8(3): 788-796.

Kouzegaran, M. R.; S.G. Moosavi and M. J. Seghatoleslami, 2015. Effect of Irrigation and Nitrogen levels on Yield and some traits of Barley. Biological Forum-An International Journal, 7(1): 470-476(2015).16.

Kumar, P.; S. Singh; R. D. Shukla and V. Singh, 2017. Effect of NPK and biofertilizer on growth and yield of barley (Hordium vulgare L.) in western uttar Pradesh. Progressive Research- An International Journal, 12 (Special-IV): 2434-2437.

Kumar, T.; J.S. Kumar; Arun and J. Dawson, 2013. Effect of different levels of nitrogen and biofertilizers on growth and yield of barley (Hordeu mvulgare 
L.), Adv. Res. J. Crop Improv., 4 (1): 59-61.

Meena, L. R.; J. S. Mann and S. L. Meena, 2012. Effect of levels and mode of nitrogen application on dual purpose barley (Hordeu mvulgare) under semiarid condition. Indian Journal of Agronomy, 57(2): 168-170.

Meena, L. R.; J. S. Mann; H. S. Jat; R. Chand and S. A. Karim, 2011. Response of multicut fodder barley (Hordeum vulgareL.) to varying levels and $\mathrm{N}$ application under semi-arid condition of Rajasthan. Indian Journal of Agronomy, 81(4): 344-347.

Mukherjee, et al., 2012. Effect of different sowing dates on growth and yield of wheat (Triticum aestivum) cultivars under mid hill situation of West Bengal. Indian J. Agron., 57(2): 152156.

Narolia, G.P. and R.S. Yadav, 2013. Effect of Nitrogen Levels and its Scheduling on Growth, Yield and Grain Quality of Malt Barley (Hordeum vulgare L.) under Normal and Late Sown Conditions in North-West Rajasthan. Annals of Arid Zone 52(2): 95-99,.

Nass, H.G.; H.W. Johnston; J.A. Macleod and D.E. Sterling, 1975. Effect of sowing date, seed treatment and foliar sprays on yield and other agronomic characters of wheat, oats and barley. Canadian J. Plant Sci., 55: 411- 47.

Odgerel, D. and D. Tserendulam, 2016. Effect of chlorella as a biofertilizer on germination of wheat and barley grains. Proceedings of the Mongolian Academy of Sciences, 56(4): 26-31.

Pal P.; M. Reddy and A. Kumar, 2018. Effect of different dates of sowing on barley (Hordeum Valgare L.) varieties under limited irrigation. Journal of Pharmacognosy and Phytochemistry, (https://onlinelibrary.wiley.com/doi/ab $\mathrm{s} / 10.1111 / \mathrm{j} .1744-$ 7348.1969.tb02847.x)

Pankaj, S.C.;, P.K. Sharma and V.K. Sharma, 2015a. Performance of barley (Hordeum vulgare L.) varieties in relation to date of sowing and nitrogen level. Agril. Res. J., 52: 89-91.

Pankaj, S.C.; P.K. Sharma; H.D. Chouksey and S.K. Singh, 2015b. Growth and development pattern of barley varieties as influenced by date of sowing and nitrogen levels. Bioscan 10: $1299-1302$.

Potterton, E. M. and T. McCabe, 2018. The effect of sowing date and nitrogen rate on the grain yield, grain quality and malt analyses of spring malting barley for distilling in Ireland. The Journal of Agricultural Science, 156 (4): 515527

Ram, H.; B. Singh and A. Sharma, 2010. Effect of time of sowing on the field performance of Barley (Hordeum vulgare) in PUNJAB. J. Res. Punjab agric. Univ., 47(3\&4): 132-135.

Rashid, A.; R.U. Khan; S.K. Marwat and Z. Ali, 2010. Response of barley to sowing date and fertilizer application under rainfed condition. World Journal of Agricultural Science, 6(5): 480-484.

Reddy B. C. and R. Singh, 2018. Effect of sowing dates and levels of nitrogen on growth and yield of barley (Hordeum vulgare L.). Int. J. Curr. Microbiol. App. Sci., (2018) 7(7): 458-464.

Safina, S. A. 2010. Effect of nitrogen levels on grain yield and quality of some barley genotypes grown on sandy soil and salinity irrigation. Egypt J. Agron., 32(2): 207-222.

Samarah, N. H. and T. A. Al-Issa, 2006. Effect of planting date on seed yield and quality of barley grown under 
semi-arid Mediterranean conditions. Journal of Food, Agriculture \& Environment, 4(2): 222-225.

Santos, V. B.; A. S. F. Araujo; L. F. C. Leite; L. A. P. L. Nunes and W. J. Melo, 2012. Soil microbial biomass and organic matter fractions dueing transition from conventional to organic farming systems. Geoderma, 170, 227-231.

Shashidhar B.C.; M.D. ; Kachapur, B.M. Chittapur, R. Hunje, 1995. Effect of crop residues on physical, chemical and biological properties of soil in sorghum based cropping systems. An abstract of seminar on Conservation of Natural Resources for Sustained Production, Nov. 1995, 16-17, UAS (Dharwad), India.

Singh, R.; D.P. Singh; N. Kumar; S.K. Bhargava1 and S.C. Barman, 2010. Accumulation and translocation of heavy metals in soil and plants from fly ash contaminated area. Journal of Environmental Biology, 31, 421-430.

Sing, J. S.; V. C. Pandey and D. P. Singh, 2011. Efficient soil microorganisms: a new dimension for sustainable agriculture and environmental development. Agric. Ecosyst. Environ., 140(3-4): 339-353.

Singh, J.; A. Singh and S.S. Mahal, 2013. Productivity and quality of malt Barley (Hordeum vulgare) as affected by sowing date, rate and stage of nitrogen application. Ind. J. Agron., 58(1): 72-80

Singh, M.; A. Chauhan; R. Kumar; D. Joshi; P. G. Soni and V. K. Meena, 2017. Dual purpose barley as affected by date of sowing, varieties and stage of harvesting-A review. Agricultural Reviews, 38 (2): 159-164. (18)

Sinha, R. K.; D. Valani; K. Chauhan and S. Agarwal, 2010. Embarking on a second green revolution for sustainable agriculture by vermiculture biotechnology using earthworms: Revising the dreams of Sir Charles Darwin, J. Adv. Biotechnol. Sustain. Dev., 2, 113-128.

Tripathi, S. C.; S. Chander and R. P. Meena, 2013, Effect of early sowing, n levels and seed rates on yield and yield attributes of different wheat (Triticum aestivum) varieties. Indian J. Agron., 58(1): 63-66.

Wali, A. M.; A. Shamseldin; F. I. Radwan; E. M. Abd El Lateef and Zaki, N. M. 2018. Response of barley (Hordeum vulgare) cultivars to humic acid, mineral and biofertilization under calcareous soil conditions. Middle East Journal of Agriculture Research, 7(1): 71-82.

Youssef, M. M. A. and M. F. M. Eissa, 2014. Biofertilizer and their role in management of plant parasitic nematodes. A review, 5(1): 1-6. 